\title{
Inledning
}

\section{Socialvetenskaplig tidskrift och svensk välfärd under ett kvartssekel}

Det här numret av Socialvetenskaplig tidskrift är ett jubileumsnummer. I år, 2019, fyller nämligen tidskriften 25 år. Första numret kom ut i juni 1994 och tidskriftens redaktion låg då i Lund.

För att uppmärksamma kvartsseklet har ett tiotal forskare bjudits in att skriva artiklar till detta tillfälle. Anledningen är att vi dels önskat få representation från olika delar av det socialvetenskapliga fältet, dels att vi vill knyta an till några av de teman som var aktuella i första årgången av tidskriften. Vid jubileer är det vanligt att blicka både bakåt och framåt.

Det välfärdssamhälle som Socialvetenskaplig tidskrift har som mål att undersöka och belysa har förändrats sedan tidskriften etablerades. En del förändringar har varit mer drastiska och andra mer subtila och inte alltid så uppenbara eftersom de skett gradvis. Vi har därför bett professor Eskil Wadensjö att skriva en inledande text om utveckling av svensk välfärd under det senaste kvartsseklet. Detta för att sätta in de övriga texterna i numret i en bredare välfärdskontext. Men framför allt har syftet varit att synliggöra den välfärdshistoria som gått jämsides med, men också påverkat, tidskriftens egen historia.

Tidskriften har på många sätt varit en tidsspegel som fångat upp aktuella tendenser i samhället och inte sällan varit en kritisk röst. Den allra första artikeln hade rubriken "Främlingar, fiender och medborgare. Bidrag till en analys av främlingsfientlighet i Sverige" (nr 1, 1994). Författare var Uppsalaforskaren Jose Alberto Diaz. Diaz konstaterar: "Frågan som många ställer sig i dessa dagar av växande etnisk intolerans är varför svenskarnas överlag liberala hållning och vänlighet mot invandrare och främlingar har förändrats på bara några år till en betydligt kyligare och även mer fientlig inställning." 
Jag satt med i redaktionen när vi publicerade artikeln 1994. Det var en text som direkt högg tag i mig och säkert i många andra. En del trodde att tendensen med den etniska intoleransen nog snart skulle blåsa över. Men så blev det tyvärr inte. När vi följer upp det främlingsfientliga temat i detta nummer av tidskriften, 25 år senare, är det uppenbart att det handlar om en mer seglivad ideologisk vändning. Artikeln i det här numret är skriven av docenten i historia Heléne Lööw. Den handlar om antisemitismen inom Nordiska motståndsrörelsen i dag. Både Diaz och Lööws texter kan ses som samtidsmarkörer på en ytterst bekymmersam samhällsutveckling.

Samtidigt sker det i dag en stark mobilisering mot främlingsfientlighet och rasism i det civila samhället. Det har förekommit många demonstrationer med bred uppslutning och även kyrkorna har visat motstånd. Allmänheten oroar sig också enligt opinionsundersökningarna för den växande främlingsfientligheten. Det är lätt att den här typen av rörelser i det civila samhället överskuggas av de mer högljudda högerextrema rörelserna.

Migrations- och integrationstemat har också behandlats i tidskriften vid andra tillfällen, till exempel i ett temanummer (nr 3-4, 2016), då frågan belystes ur olika perspektiv. Också de ensamkommande flyktingbarnen och deras mobilisering för grundläggande sociala rättigheter behandlades.

En viktig aspekt av integrationstemat är de utrikes föddas etablering på arbetsmarknaden. Det är en viktig fråga både ur samhällets och ur individens perspektiv. En förutsättning för att kunna integreras i samhället är möjligheterna att få ett förvärvsarbete. Professor Mats Hammarstedts artikel "Utrikes föddas etablering på arbetsmarknaden - en viktig fråga för välfärdens finansiering" i det här numret visar detta. Hammarstedt konstaterar att av Sveriges drygt tio miljoner invånare år 2019 är närmare 20 procent födda i något annat land än Sverige. Han framhåller att en fungerande arbetsmarknadsetablering för utrikes födda är av största vikt med hänsyn till den förändrade åldersstrukturen i befolkningen, men också för välfärdens finansiering i framtiden.

Socialvetenskaplig tidskrift har under årens lopp återkommande arbetat med temanummer, inte sällan med särskilda gästredaktörer. Redan i nr 2-3 i första årgången 1994 publicerades ett temanummer om familjeforskning som professor Gunvor Andersson var gästredaktör för. Ett annat exempel är temanumret Svensk välfärd under 100 år. Professor Margareta Bäck-Wiklund var gästredaktör för detta nummer (nr 2-3, 2003). Båda temanumren lyfter bland annat fram kvinnornas roll inom välfärden och socialpolitiken, vilket annars ofta har varit en förbisedd fråga.

Ytterligare ett exempel på en tidigare artikel på temat är professor Rolf Ohlssons "Det svenska välfärdssamhällets framväxt - tacka kvinnorna för det" (nr 1, 1995). Ohlsson kritiserar den socialvetenskapliga välfärdsforskningen för att alltför mycket ha varit inriktad på institutionella och politiska förhållanden och tagit för lite hänsyn 
till demografiska och ekonomiska faktorer. Ohlsson visar att en viktig drivkraft för familjepolitikens framväxt var behovet av kvinnor i arbetslivet.

I det här jubileumsnumret får professor Maria Stanfors föra familjeforskningstraditionen vidare. Hennes artikel har titeln "Familjen i välfärdspolitiken". Stanfors visar att Sverige i hög grad utmärker sig i positiv bemärkelse på detta område. Hon konstaterar att vårt land har mer jämställdhet, jämfört med andra industriländer i väst. Sverige och övriga Norden är exempel på länder där kvinnor i hög grad kan kombinera förvärvsarbete och familj, visar hon.

Till familjen hör också barnen. Den sociala barnavården är ett tema som återkommit i tidskriften. Inte minst har stockholmsprofessorerna Tommy Lundström och Marie Sallnäs medverkat flera gånger. I detta nummer gör de det med en artikel som har titeln "Barnskyddets innersta kärna - om tvångsplaceringar som motiveras av barns hemförhållanden". Författarna diskuterar bland annat de framtida utmaningar som den sociala barnavården står inför. Utmaningen är att dels möta de ökade kraven på att barns intressen ska sättas i centrum, dels ett ökat krav på att socialtjänsten ska göra riskbedömningar för att förebygga omhändertaganden. Sådana krav innebär att den sociala barnavården i ökad utsträckning kommer att få hantera intressen som kan stå i stark konflikt med varandra.

De flesta medborgare i landet har fătt det ekonomiskt bättre med ökade inkomster och högre levnadsstandard under det senaste kvartsseklet. Samtidigt har villkoren i välfärden förändrats efter den ekonomiska krisen på 1990-talet med en ökad arbetslöshet och neddragningar i socialförsäkringarna. Det har drabbat grupper som inte hängt med i utvecklingen i samma takt som majoriteten av invånarna. Det gäller framför allt grupper som inte har etablerat sig på arbetsmarknaden och kommit in i socialförsäkringssystemet.

Kort uttryckt har de rikare blivit rikare och de fattiga fattigare. Ett mått på det är att de ekonomiska klyftorna har ökat mätt med Gini-koefficienten. Den svenska välfärdsmodellen har också fått ett större inslag av konkurrens och privatisering. Exempel är den privatisering av driften av sjukvård, äldreomsorg, barnomsorg och skola som skett. Privata sjukvårdsförsäkringar har blivit vanligare och bostadsmarknaden har långtgående avreglerats. Vi har också rört oss mot en mer individualistisk syn på olika sociala problem och samhällssolidariteten har minskat. Allt detta måste ses som ett avsteg från grundtanken i den universella välfärdsmodellen som länderna i Norden varit så kända för.

Inte minst har socialtjänsten, som välfärdens yttersta skyddsnät, påverkats av de förändringar som ägt rum. Verksamheten står i dag inför stora utmaningar. Tre andra artiklar i det här numret illustrerar detta.

Sverige håller på att åldras, medellivslängden har successivt ökat och det finns inget som tyder på att den stannar av inom den närmaste framtiden. Konsekvenserna 
är att medborgarna blir äldre och fler förväntas ställa krav på den framtida välfärden. Docent Tove Harnetts artikel handlar om den kommunala äldreomsorgen och frågan om avvägningen mellan ålder och behov vid bedömningen av rätt till stödinsatser. Artikeln har titeln "Utifrån ålder eller behov? Ålder som organiserande princip för stödinsatser till äldre".

Även om 1990-talets ekonomiska kris drabbade både socialförsäkringarna och socialtjänsten och ledde till avregleringar och besparingar skedde det också en del nya satsningar. En lagstiftning som är jämnårig med Socialvetenskaplig tidskrift är lagen (1993:387) om stöd och service till vissa funktionshindrade, LSS. Den trädde i kraft 1994 och gav kommunerna ansvar för tio olika insatser som syftade till att öka delaktigheten för målgruppen. Året efter kom Psykiatrireformen och därmed nya perspektiv och så småningom också ett nytt verksamhetsfält.

Professor Urban Markström visar att detta verksamhetsfält står inför en rad utmaningar, både när det gäller att beakta brukarnas egna erfarenheter och medverkan men också frågan om tillgänglighet och samordning mellan olika instanser.

Nästa artikel, som också har ett framtidstema, handlar om automatiseringen inom socialtjänstens handläggning av försörjningsstöd. Några kommuner har inlett försöksverksamheter och det finns stora framtidsförväntningar om att administrationen med socialbidragen ska kunna förenklas och göras mer rättvis. Universitetslektor Lupita Svensson belyser för- och nackdelar med systemet och vilken roll det kan komma att få i framtiden. Än så länge är forskningen begränsad inom fältet och det finns därför anledning att belysa, kritiskt granska och följa de pågående försöken.

En av artiklarna i numret handlar om socialarbetarnas möjligheter att göra sig hörda i samhället och att medverka och debattera socialt arbete i de elektroniska medierna genom särskilda podcaster, som blir allt vanligare. universitetslektor Jörgen Lundälv har skrivit artikeln "Välfärden, samhällskritiken och medierna - socialarbetares röster i podcaster i socialpolitik och socialt arbete". Han visar att podcaster blir alltmer populära även hos myndigheterna. För att nämna ett exempel, producerar Socialstyrelsen en podcast om socialtjänst och hälso- och sjukvård som kallas "På djupet - en podd från Socialstyrelsen".

Lundälvs artikel kan också ses som ett exempel på digitaliseringens och de elektroniska mediernas utbredning i samhället på bekostnad av tryckta alster. Den utvecklingen har en direkt anknytning till Socialvetenskaplig tidskrifts egen historia.

Den kanske största förändringen för tidskrifterna under det senaste kvartsseklet är skiftet från analog till digital teknik. Tidskriften läses numera huvudsakligen elektroniskt. Det följer en övergripande trend i samhället med att papperstidskrifterna försvinner och vi får våra kunskaper genom den digitala tekniken. Det finns många fördelar med elektroniska tidskrifter. De kan distribueras billigare. Utgivaren slipper tryckkostnader, porto och andra transportkostnader och behöver inte heller begränsa omfånget. De går 
snabbare att publicera, det är lättare att göra tillägg och uppdateringar och att öka spridningen av texterna som på så sätt görs mer tillgängliga för olika grupper.

Det finns dock också en rad nackdelar med den ökande elektroniska publiceringen. Den tekniska utvecklingen ställer krav på hård- och mjukvara för att göra vissa artiklar tillgängliga och det är svårt att kvalitetssäkra tidskrifter i det förändrade digitala tidskriftslandskapet. Det har också utvecklats så kallade rovdjurstidskrifter som mot betalning erbjuder publicering av forskningsartiklar. Det är inte lätt att hålla ordning i denna djungel av tidskrifter.

Tidskriften forskning.se., som är en helt elektronisk publikation, intervjuade Åsa Wikforss, professor i teoretisk filosofi vid Stockholms universitet, i samband med att hon nyligen valts in i Svenska akademien (https://www.forskning.se/2017/04/27/ faktaresistens-en-fara-for-planeten/). Texten har titeln "Faktaresistens - en fara för planeten".

Wikforss betonade i intervjun att debattklimatet i samhället håller på att bli mer polariserat, känsloladdat och kategoriskt. Det sker en förskjutning från vetenskaplig argumentation till politisk propaganda, menar hon.

"Kunskapsresistensens kärna är förnekandet av evidens. Kunskap kräver att det finns en evidens, annars är det bara tro eller mer eller mindre lyckade gissningar [...]. Både den individuella överlevnaden och samhällets överlevnad bygger på att vi har kunskap. Därför är den utveckling vi har just nu så oroväckande ...", konstaterar Wigforss.

Just på grund av denna samhällsutveckling har det sällan känts mer relevant att fira ett 25-årsjubileum av Socialvetenskaplig tidskrift som värderar kvalitén högt. Tidskriften har sedan starten både en redaktion, ett redaktionsråd och använder utomstående bedömare för att granska och förbättra texterna som godkänns för publicering.

Det är många som under åren har varit verksamma i redaktioner och redaktionsråd och lagt ner ett stort arbete på att läsa och bedöma artiklar och föreslagit förbättringar. Socialvetenskaplig tidskrift har sedan starten varit noga med att ha personer från olika vetenskapliga discipliner i redaktion och redaktionsråd med ambitionen att täcka in olika delar av det socialvetenskapliga forskningsfältet.

Tidskriften har också haft som mål att cirkulera mellan de olika universitetsmiljöerna och har haft sin hemvist vid universiteten i Lund, Göteborg, Umeå och återigen i Lund. Tidskriften har haft fyra huvudredaktörer, nämligen Stig Larsson, Margareta Bäck-Wiklund, Stina Johansson och Anna Meeuwisse. Efter detta nummer kommer Socialvetenskaplig tidskrift att få sin hemvist vid Linköpings universitet och Magnus Dahlstedt blir redaktör.

Sedan starten ägs tidskriften av FORSA, Förbundet för forskning i socialt arbete. Förbundet grundades av en grupp entusiastiska forskare, doktorander och forskningsanvändare 1984 vid en konferens i Lövånger i Västerbotten. Forskarutbildningen i 
socialt arbete hade då nyligen startat i Göteborg, Stockholm och Umeå och doktorander hade antagits $i$ ämnet.

Bengt Börjeson, som blev professor i socialt arbete i Umeå 1981 och var en frontfigur i socialt arbete vid denna tid, valdes till första ordförande i FORSA. Förbundet har sedan starten arbetat för att stärka samarbetet mellan forskning, utbildning och det sociala arbetets praktik.

Stig Larsson, som hade varit medlem i styrelsen för FORSA från starten, blev ordförande i förbundet 1992. Styrelsen gav honom i samband med detta i uppdrag att försöka få till stånd en svenskspråkig socialvetenskaplig tidskrift som skulle stärka länken mellan universitetsforskningen och forskningsanvändarna. Larsson hade tidigare erfarenhet av tidskriftsarbete. Han hade bland annat varit engagerad i tidskriften Nordisk Sosialt Arbeid, som grundades 1980 av Nordiske sosionomforbunds samarbeidskomité.

Att ge ut en svenskspråkig tidskrift var viktigt för förbundet. Dels skulle författarna kunna få skriva på originalspråket eftersom de olika välfärdssystemen ser så olika ut. Dessutom skulle det vara lättare att nå ut till de praktiskt verksamma och inte bara till etablerade forskare.

År 1993 beviljades tidskriften medel från dåvarande Socialvetenskapliga forskningsrådet och kunde starta 1994. Sedan dess har Forskningsrådet för arbetsliv och socialvetenskap och nuvarande Forte - Forskningsrådet för hälsa, arbetsliv och välfärd beviljat publikationsstöd.

Tidskrift är ett fint och intressant ord. Det handlar om skrift i tiden. Om skrivna ord. Om texter som återkommer med en viss periodicitet. Socialvetenskap handlar om forskning om samhället, socialpolitik, välfärd, sociala relationer, social trygghet, om allt som sker mellan födsel och död och mycket mer. Forskning är en yrkesverksamhet. Bakom varje artikel ligger i regel många års forskning och ibland ett helt yrkeslivs samlade vetande. I tyckarbubblornas och faktaresistensens tid finns det skäl att hylla de skrivna orden som bygger på vetenskapliga undersökningsmetoder och noggranna studier.

Alla vi som arbetat med detta nummer är mycket stolta över att presentera de tio texter som följer. Vi vill också rikta ett stort tack till alla som under det senaste kvartsseklet bidragit till att bevara det skrivna ordet i en turbulent samtid.

För att använda filosofiprofessorn Åsa Wikforss ordbruk önskar jag, som var med om att starta Socialvetenskaplig tidskrift och som har varit gästredaktör för detta nummer, att den också under det kommande kvartsseklet ska kunna verka som ett bålverk mot den desinformation och nedmontering av kunskap som nu håller på att ske.

\section{Hans Swärd}

